\title{
Corporate Governance, Market Share, and Intellectual Capital Disclosure: Evidence from the Indonesian Agriculture and Mining Sectors
}

\author{
Saarce Elsye Hatane ${ }^{1}$ \\ Elenne Stefanie Kuanda ${ }^{2}$ \\ Elizabeth Cornelius ${ }^{3}$ \\ Josua Tarigan ${ }^{4}$ \\ ${ }^{1,2,3,4}$ Faculty of Business and Economics, Universitas Kristen Petra, Indonesia \\ email: elsyehat@petra.ac.id
}

DOI: https://doi.org/10.24843/JIAB.2020.v15.i01.p07

\begin{tabular}{l}
$\begin{array}{l}\text { Jurnal Ilmiah Akuntansi } \\
\text { dan Bisnis } \\
\text { (JIAB) }\end{array}$ \\
\hline Volume 15 \\
Issue 1 \\
January 2020 \\
Page 76 - 84 \\
p-ISSN 2302-514X \\
e-ISSN 2303-1018 \\
\hline ARTICLE INFORMATION: \\
\hline Received: \\
30 May 2019 \\
Revised: \\
01 November 2019 \\
Accepted: \\
08 January 2020 \\
\hline
\end{tabular}

\section{INTRODUCTION}

Presently, firms are entering a knowledge-based era, where the economy is growing with the usage of science and technology. Therefore, firm value is no longer considered solely based on financial performance, but also the performance of intangible assets (Berzkalne \& Zelgalve, 2014), such as intellectual capital. Several examples of intellectual capital in a company are employee performance, the firm's capability to innovate, technology usage, and the company's reputation in society (Maaloul \& Zéghal, 2015). One of the instruments used to communicate intellectual capital is annual report.

An et al. (2011) expressed that companies who disclose intellectual capital will earn several benefits. According to Cheng et al. (2010), firms' market value will increase by 80 percent when they disclose their ICs. Firstly, companies can reduce intellectual capital between the management and stakeholders. By disclosing IC, firms may also reduce insider trading as all information would have been disclosed. Firms can also uphold its integrity in front of the stakeholders. The companies that revealed IC to stakeholders, give a signal that they have worked in accordance with existing norms, thus being seen as reputable in the public's eyes and diverted stakeholders' attention from negative issues. A good reputation may also help a company to gain new investors.

Corporate governance is necessary to develop transparency between a company and both its stakeholders and shareholders (Abeysekera, 2010). As a result, corporate governance is established to ensure that the management has made decisions that fit the expectations of stakeholders and shareholders; as well as confirming that firm's management has provided information to all stakeholders. The measures of corporate governance in this study are board size, auditor types, and audit committee.

Indonesia is chosen to be the object in this study as it is a nation with the largest GDP and population in the ASEAN Economic Community (AEC) 
(Kijboonchoo et al., 2018). According to data from the World Bank in 2017, Indonesia has a GDP of USD 1,015 trillion and a population of 263,991,379. This signifies a considerable amount of human resources. Čepar \& Bojnec (2008) investigated the importance of demographic processes for the availability of human capital which in turn may impact to the financial performance. Optimal human resources management may help maximize firm performance. The big number of population which is supported by expanding education level have positive influence on the human capital accumulation (Hermannsson \& Lecca, 2014). Besides, the score of IC disclosure in Indonesia tends to remain low. According to Mukhibad \& Setyawati (2019), the average score for IC disclosure of LQ 45 companies in 2014-2017 was 56.35\%.

The importance of IC does not only attract the attention of companies and investors, but also researchers. Several studies have been done to find out what factors affect intellectual capital (IC) disclosure. Ousama et al. (2012) found that the auditor type does not affect IC disclosure, but Whiting and Woodcock (2011) discovered that auditor type positively affects IC disclosure. Rashid et al. (2012)'s study revealed that board size significantly influences IC disclosure, while Bhatia and Argawal (2015) concluded that board size does not influence IC disclosure. Likewise, Ho \& Wong (2011) and Buallay (2018) reported that audit committee has an impact on information shared by companies, including on intellectual capital disclosure; on the other hand, $\mathrm{Li}$ et al. (2012) stated that audit committee has no impact on intellectual capital disclosure (ICD).

There are two categories of results, the consistent and inconsistent variables in influencing the ICD. According to the results gap, this study needs to be done to provide additional empirical studies to support researches in ICD. This study examines the determinant factors in ICD, particularly in agriculture and mining sectors. The agriculture sector is chosen because based on the results of the Rice Market Monitoring (RMM) by the Food and Agriculture Organization of the United Nations (FAO) shows that Indonesia is one of the largest rice producing countries in the world in 2017. In addition, the agricultural sector accounts for $14.3 \%$ of total GDP, and absorbs the workforce by $38.9 \%$ (Kementrian Pertanian Republik Indonesia, 2017). In contrast to the performance of agriculture, the mining sector in Indonesia experienced a downturn due to falling world commodity prices (Dwiarto, 2018). In addition, the amount of investment in the mining sector has also decreased, this is due to inconsistent regulations and overlapping authority. Nevertheless Indonesia's opportunities to increase investment in the future remain (Oxford Business Group, 2018). Human resources, innovation, and technology are important components of intangible assets for these two sectors, which are part of creating intellectual capital. The different performance in the two sectors that prompted this research to examine the factors that influence companies in these two sectors can reveal activities related to efforts to create intellectual capital.

This study uses two theories that form the basis of hypotheses that are built related to the factors that influence IC disclosure. The first is the stakeholder theory, which explains that a company's management activities should comply with the wish or approval of stakeholders, and all activities done should be reported to all stakeholders (Freeman, 1984). Every stakeholder owns the same right to receive the company's inside information, thus they could ensure that the company has been working optimally. Although not all information received will be used eventually. It is intended that stakeholders can ensure that management has utilized all the potential that exists in the company. Therefore IC disclosure is an approach that can be done by companies to provide information to stakeholders (Bruggen et al., 2009). Large companies are indicated by a large market share and good governance. Using a stakeholder theory framework, large companies tend to have more and more diverse stakeholders. Therefore companies will be more required to disclose information in order to meet the interests of stakeholders.

The second one is the legitimacy theory, where a company must guarantee that it has been operating in compliance with existing norms and boundaries (Guthrie et al., 2004). This theory emphasizes that the company is in the process of adjusting its existence to the norms or social values around it; or the company believes in the social-contract principle (Kamath, 2017). This theory is closely related to the disclosure of IC as a form of accountability from the company to show if the activity is in accordance with social norms and values (Hossain, 2011).

Intellectual capital disclosure, as part of a firm's intangible asset, is difficult to measure, and thus is not reported in the balance sheet (Roos and Roos, 1997). Sveiby (1997) divided IC into 3 categories: 
human capital (HC), structural capital (SC), and relational capital (RC). $\mathrm{HC}$ is the core component in IC (Chowdhury et al., 2018) and encompasses employees' competence, including their education, knowledge, skill, and experience, which are useful to achieve company's goal. SC is the intellectual property possessed by a company, for example business processes, usage of technology, trademark, and firm's capability to innovate (Bhasin, 2012). RC covers the relationship between a company and its external parties, such as company's reputation in public, and includes its relation with stakeholders (customers, creditors, suppliers) (Guthrie et al., 2012).

Professional public accounting firms like the Big 4 will urge their clients to disclose information thoroughly, in order to provide the real, complete picture of the company for annual report users (Chao \& Gray, 2010). By doing it, audit firms deliver signal to the public that they are maintaining their audit quality (Ousama et al., 2012). Since disclosing and verifying IC may need additional skills, a qualified auditor is necessary to strengthen the disclosure's credibility (Ferreira et al., 2012). Consequently, a company audited by the Big 4 is expected to disclose more IC-related information, as it is employing an auditor capable of verifying the truth of information and assuring annual report users.

The relationship between auditor type and ICD has been studied previously. Whiting and Woodcock (2011) and Oliveira et al., (2006) found a positive relation between auditor type and ICD. From this, the following hypotheses are defined:

$\mathrm{H}_{1 \mathrm{a}}$ : Auditor type significantly and positively affects HCD.

$\mathrm{H}_{1 b}$ : Auditor type significantly and positively affects SCD.

$\mathrm{H}_{1 \mathrm{c}}$ : Auditor type significantly and positively affects RCD.

Board size is shown through the number of members on the board. According to agency theory, the large number of board members can increase the effectivity of supervision and control (Al Azees et al., 2019), which will be reflected in annual reporting disclosure. Compared to a smaller number of board members, more board members equate more experience, viewpoint, and various differing skills (Abeysekera, 2010). This may become an added value in the company's future, whether from HC or RC (Massingham \& Tam, 2015; Whiting \&
Birch, 2016), which will be voluntarily disclosed in the annual report.

Larger board size may lead to communication difficulty and decision-making inefficiency, but the benefits outweigh the possible problems (Whiting and Birch, 2016). This is supported by Hidalgo et al. (2011) and Haji \& Ghazali (2013), who found a positive relationship between board size and ICD. From this explanation, the hypotheses on the relation between board size and ICD in Indonesia are:

$\mathrm{H}_{2 \mathrm{a}}$ : Board size significantly and positively affects HCD.

$\mathrm{H}_{2 \mathrm{~b}}$ : Board size significantly and positively affects SCD.

$\mathrm{H}_{2 \mathrm{c}}$ : Board size significantly and positively affects RCD.

There have been many prior studies on the relationship between the audit committee and ICD. More audit committee members can offer various viewpoints, opinions, and skills in addressing problems that exist in the financial reporting process, while also providing effective supervision (Li et al., 2012). Other than guaranteeing stakeholders' interests, the audit committee is also responsible in finding and resolving issues, particularly in the preparation of reports, such as the company's financial and interim reports ( $\mathrm{Li}$ et al., 2012). Hence, the audit committee owns a role in disclosing the firm's information, including those of IC. Madi et al. (2014) and Ahmed Haji (2015) determined that there is a relation between the audit committee and ICD. Thus, the following hypotheses on the relationship between the audit committee and ICD in Indonesia are defined:

$\mathrm{H}_{3 \mathrm{a}}$ : Audit committee significantly and positively affects HCD.

$\mathrm{H}_{3 \mathrm{~b}}$ : Audit committee significantly and positively affects SCD.

$\mathrm{H}_{3 \mathrm{c}}$ : Audit committee significantly and positively affects RCD.

This research also uses several control variables based on previous studies on ICD: firm size, market share, profitability, and leverage. A large firm tends to have more activities, resources, and higher agency cost compared to a small firm (Ousama et al., 2012). Additionally, a large firm would have more stakeholders and interests that the company needs to fulfill. Thus, firm size is chosen as a control variable.

When a company has gained a good reputation and trust from the public, it tends to not disclose more 
than what is necessary, as it has no further benefits, creates additional costs, and could potentially lead competitors to exploit the information in order to harm the company(Bagchi etal., 2015). This explanation incites the use of market share as the next control variable.

A firm with high profitability would naturally like to signal its achievements to stakeholders. Disclosure is seen as one of the way the company can signal that it has a good performance (Ousama et al., 2012). By contrast, a company with high leverage would disclose more information, including IC-related information, in order to mitigate the high agency cost. Information on IC may also become supporting information, where the company does not rely only on financial information, but also focuses in creating value for the future (Ousama et al., 2012).

\section{RESEARCH METHOD}

This study uses annual reports published by Indonesian companies in the agricultural and mining sectors. The research period is 5 years, from 2013 to 2017. The population is 21 agricultural and 43 mining companies. Using a purposive sampling technique, in which the company must be listed in Indonesia Stock Exchange (IDX) and has a complete annual report in the period of 2013 until 2017. The final sample is 18 agricultural and 28 mining companies, in total resulting in 230 units of analysis. Hypothesis testing of the effect of independent variables and dependent variables will use regression panel model. Utilizing panel testing, it will be known whether the hypothesis should be tested with a fixed effect model (FEM), random effect model (REM), or ordinary least square (OLS) model. The weighted least squares (WLS) and generalized least squares (GLS) models will also be used if the FEM or REM models contain heteroscedasticity. The gretl software is used in determining the models and testing hypothesis, where the data will pass through panel data testing that consists of F-test, Breusch-Pagan test, and Hausman test.

The ICD variable is measured using the content analysis method. Each annual report is read manually in order to find ICD-related information. To reduce subjectivity in the content of the analysis, a reassessment was conducted between researchers for each item on the ICD list. The items in the ICD are adapted from Yau et al. (2009), consisting of 30 HCD items, 22 SCD items, and 18 RCD items). A score of 0 to 3 is given for each ICD information obtained. A score of 0 is given if there is no disclosure,
1 if the information is narrated, 2 if the information is combined with numerical data, and 3 if it is shown with monetary data. The total score is divided with the total item into each ICD components. Auditor type is a dummy variable, marked 1 if the company uses the service of Big 4 accounting firms and 0 if it doesn't. Board size is measured using the number of members on the board of commissioners (BoC), and audit committee is measured by the number of members of the audit committee.

Variable controls used are firm size, market share, profitability, and leverage. Firm size is calculated with the natural logarithm of total assets, market share with the ratio of firm sales on industry sales, profitability by using the return on asset ratio, while leverage is calculated with the ratio of total debt on total equity. All financial data are taken from Bloomberg. The equation applied as follow. $\mathrm{HCD}_{\mathrm{t}}, \mathrm{SCD}_{\mathrm{t}}, \mathrm{RCD}_{\mathrm{t}}=\beta_{0}+\beta_{1} \mathrm{ATYPE}_{\mathrm{t}}+\beta_{2} \mathrm{BSIZE}_{\mathrm{t}}$ $+\beta_{3}$ AUDITCOM $_{t}+\beta_{4}$ FSIZE $_{t}+\beta_{5}$ MSHARE $_{t}+\beta_{6}$

Where: $\mathrm{PROF}_{\mathrm{t}}+\beta_{7} \mathrm{LEV}_{\mathrm{t}}+\varepsilon$.......(1)

$\begin{array}{ll}\text { HCD } & =\text { Human Capital Disclosure, } \\ \text { SCD } & =\text { Structural Capital Disclosure, } \\ \text { RCD } & =\text { Relational Capital Disclosure, } \\ \text { ATYPE } & =\text { Auditor Type, } \\ \text { BSIZE } & =\text { Board of Commissioner Size, } \\ \text { AUDITCOM } & =\text { Audit Committee, } \\ \text { FSIZE } & =\text { Firm Size, } \\ \text { MSHARE } & =\text { Market Share, } \\ \text { PROF } & =\text { Profitability } \\ \text { LEV } & =\text { Leverage } \\ \varepsilon & =\text { error, } \\ \mathrm{t} & =\text { year }(2013-2017)\end{array}$

\section{RESULTS AND DISCUSSION}

The descriptive analysis in this research details the average score (mean), standard deviation, minimum score, and maximum score of independent and dependent variables.

Table 1. shows the average scores of HCD, SCD, and RCD are 0.7 and above. This means the disclosures provided are generally only in the form of narration. These could have been complemented with numerical or monetary data, considering the average firm size is around 12.375 , approaching the maximum score. The average scores of $\mathrm{BoC}$ and audit committee are 3 , market share is $4.1 \%$, and profitability is $1.4 \%$. The ratio for leverage ranges between $2039 \%$ and $2719 \%$ with an average of $103.5 \%$. 
Table 1. Descriptive Statistics

\begin{tabular}{lllll}
\hline Variables & Mean & Std & Min & Max \\
\hline HCD & 0.798 & 0.286 & 0.300 & 1.533 \\
SCD & 0.749 & 0.187 & 0.091 & 1.273 \\
RCD & 0.794 & 0.333 & 0.222 & 1.722 \\
Board Size & 3.643 & 1.927 & 1.000 & 10.000 \\
Audit Committee & 3.035 & 0.450 & 1.000 & 6.000 \\
Firm Size & 12.735 & 0.558 & 11.196 & 13.967 \\
Market Share & 0.041 & 0.059 & 0.000 & 0.351 \\
Profitability & 0.014 & 0.117 & -0.705 & 0.388 \\
Leverage & 1.035 & 3.483 & -20.390 & 27.192 \\
\hline
\end{tabular}

Source: Processed Data, 2019

Table 2 demonstrates the descriptive statistics of the auditor type. Around half of the companies studied (53.91\%) use the service of Big 4 accounting firms.

Table 2. Descriptive Statistics (Dummy Variable)

\begin{tabular}{lll}
\hline Variable & Frequency 1 & Frequency 0 \\
\hline Auditor Type & 0.5391 & 0.4609 \\
\hline Source: Processed Data, 2019 & &
\end{tabular}

Table 3 describes the scores of the p-value $(F)$ are below 0.05 , so the model can be tested using pooled OLS. VIF score shows the presence of multicollinearity if it is $>10$, thus the study is free from multicollinearity. However, all three variables contain heteroscedasticity as the scores of the white test are below 0.01 , hence this study uses WLS (Weighted Least Squares), since the panel shows fixed effect (Klein et al., 2016).

Table 3. Pooled OLS, Collinearity, and Heteroscedasticity

\begin{tabular}{lcccc}
\hline & HCD & SCD & RCD & VIF \\
\hline Auditor Type & -0.024 & $0.058^{* *}$ & $-0.081^{*}$ & 1.323 \\
BOC Size & -0.012 & -0.008 & $-0.043^{* * *}$ & 1.327 \\
Audit Committee & $0.130^{* * *}$ & $0.155^{* * *}$ & $0.136^{* * *}$ & 1.145 \\
Firm Size & $0.326^{* * *}$ & $0.088^{* * *}$ & $0.285^{* *}$ & 1.856 \\
Market Share & $-0.982^{* * *}$ & 0.198 & 0.010 & 1.736 \\
Profitability & $0.316^{* *}$ & 0.118 & 0.151 & 1.101 \\
Leverage & -0.004 & 0.003 & -0.002 & 1.006 \\
P-Value (F) & $3.45 \mathrm{E}-18$ & $5.55 \mathrm{E}-19$ & $3.90 \mathrm{E}-09$ & \\
Adjusted & 0.335 & 0.347 & 0.187 & \\
Square & & & & \\
Heteroscedasticity & 0.000 & 0.003 & 0.001 & \\
\hline
\end{tabular}

Source: Processed Data, 2019

Table 4 demonstrates the result of panel testing ofdependent variables. HCD and SCD are tested using WLS since they have fixed effect and contain heteroscedasticity. RCD is examined with GLS as it also has heteroscedasticity.

Table 4. Panel Test

\begin{tabular}{llll}
\hline & HCD & SCD & RCD \\
\hline Fixed Effect Estimator & $3.65 \mathrm{E}-53$ & $1.71 \mathrm{E}-31$ & $5.90 \mathrm{E}-67$ \\
& Fixed Effect & Fixed Effect & Fixed Effect \\
Breusch-Pagan Test & $1.26 \mathrm{E}-50$ & $9.13 \mathrm{E}-35$ & $1.12 \mathrm{E}-67$ \\
& Random Effect & Random Effect & Random Effect \\
Hausman Test & 0.00276819 & 0.032225 & 0.10315 \\
& Fixed Effect & Fixed Effect & Random Effect \\
Conclusion & Fixed Effect & Fixed Effect & Random Effect \\
Model Used & WLS & WLS & GLS \\
\hline
\end{tabular}

Source: Processed Data, 2019 
Table 5 displays the result of hypotheses testing. Auditor type, statistically, only affects SC disclosure. The positive influence means firms audited by the Big 4 disclose more information than those who are not. Professional accounting firms i.e. Big 4 commonly maintain their audit quality, for example by helping to reduce information asymmetry between the management and stakeholders (Ahmad and Bouri, 2017). Audit firms also act as a bridge between companies' internal and external parties (Khlif and Souissi, 2010). A competent audit firm would encourage a firm to disclose information to ensure stakeholders gain a full picture of the company. This complete understanding naturally helps stakeholders in making the right decision.

Compared to smaller audit firms, the Big 4 owns a more capable resource and stronger influence in driving companies to disclose information. Small audit firms ordinarily only perform audit procedure to maintain a good relationship with companies, while influential audit firms will push firms to increase reporting quality, as a way of preserving and upholding a good relationship with their clients (Malone et al., 1993).

Table 5. Panel Regression

\begin{tabular}{lccc}
\hline & HCD & SCD & RCD \\
\hline Auditor Type & 0.016 & $0.042^{* * *}$ & -0.066 \\
BOC Size & $-0.014 * *$ & $-0.012 * * *$ & 0.011 \\
Audit Committee & $0.060^{* *}$ & $0.171^{* * *}$ & 0.005 \\
Firm Size & $0.3115^{* * *}$ & $0.091 * * *$ & $0.114 *$ \\
Market Share & $-0.652^{* *}$ & $0.169^{*}$ & 0.598 \\
Profitability & $0.169^{* *}$ & $0.183^{* * *}$ & -0.038 \\
Leverage & -0.001 & 0.001 & -0.000 \\
P-Value (F) & $1.25 \mathrm{E}-33$ & $2.48 \mathrm{E}-34$ & 0.119 \\
Adjusted R-Square & 0.524 & 0.531 & 0.076 \\
Note: significant on the level: $* * *=1 \% ; * *=5 \% ; *=10 \%$ \\
\hline SOurce: Processed
\end{tabular}

Source: Processed Data, 2019

Supporting the stakeholder theory, independent and proficient audit firms will persuade companies to fulfill stakeholders' rights in earning information related to inside activities that may affect decision making. Additionally, a good audit firm can also increase the incredibility of a disclosure (Oliveira et al., 2006). They make sure that the information disclosed by the firm is correct and accountable. This result supports the legitimacy theory, where a company must guarantee that it has been operating in compliance with existing norms and regulations. By auditing and urging the company to release quality annual reports, audit firms can protect their reputation in public. The result of this study confirmed the results of Whiting \&Birch (2016), Ahmadi \&Bouri (2017), and Atan \& Rahim (2012); but it also contradicts the research of Ousama et al. (2012) and Rashid et al. (2012), both of which did not find any significant relationship between auditor type and IC disclosure.

Board size, measured with the number of members in $\mathrm{BoC}$, has an influence in IC disclosure in Indonesia, especially in $\mathrm{HC}$ and $\mathrm{SC}$ disclosure. But in contrast with the study by Rashid et al. (2012) who found a positive relationship between board size and ICD, this research found the reverse (negative relationship). This indicates that more members in board of commissioners means less disclosure by the firms.

A large number of board members should be able to contribute various views and expertise within the company. The current technology growth causes the need for technological skills and knowledge in the company's operational activities. Hence, more board members mean more necessary knowledge and expertise in order to make the right decision (Rashid et al., 2012). Despite this, sample firms apparently do not feel this benefit would outweigh the problems caused by a large number of board members. Excess board members may cause difficult decision-making and poor communication, leading to less disclosure (Cerbioni \& Parbonetti, 2007). Further, a company with many board members will find difficulties in controlling the management (CEO). Irayaet al. (2015) and Aygun et al. (2014) found that the larger the board size, the higher the earning management done by the company's managers. A similar view was expressed by Cerbioni \& Parbonetti (2007), where the quality of supervision is inversely related to the number of board members. The result of the study matches those of Cerbioni \& Parbonetti (2007) and Alizaedah et al. (2014), who discovered a negative relationship between internal information disclosure and board size. At the same 
time, the study disproves the results of Whiting \& Birch (2016) and Haji \& Ghazali (2013).

Audit committee affects IC disclosure, particularly on HC and SC. Audit committee guarantees that shareholders' interests will be fulfilled through reporting and internal control. Ho \& Wong (2001) also found a link between the audit committee and a more trustworthy, qualified, and substantial reporting. For this reason, the audit committee is capable of increasing the amount of information shared by the company.

The audit committee is tasked with improving and safeguarding internal control. The audit committee also has a role as a supervisory tool over the company's disclosure practice (Li et al., 2012). Larger audit committee usually pours more resource and expertise in order to effectively fulfill its responsibilities (Allegrini \& Greco, 2011; Li et al., 2012). The audit committee is also responsible for finding and resolving issues, particularly in the preparation of reports, such as the company's financial and interim reports. Accordingly, the audit committee owns a role in disclosing the firm's information, including those of IC. The result of this research corresponds those by Mondal and Gosh (2014), Madi et al. (2014), Ahmed Haji (2015), Buallay (2018) who found a positive association between the audit committee and ICD.

Table 5 shows that firm size affects all ICD components, meaning the larger a firm is, the more it discloses IC. It is because a large firm tends to have more resource, activities, and stakeholders. Since stakeholders' interest and supervision can be met through disclosure, the result supports the research of Yau et al. (2009) and Jindal and Kumar (2012).

Market share has negative and positive effects on HCD and SCD, respectively. It is measured by dividing firm sales with industry sales. When a company has gained public trust, it is obliged to disclose the information related to resource management and the company's inside activities. Yet sometimes, to avoid the dissemination of competitive advantage that may instead turn it into a competitive disadvantage, several disclosures will be reduced.

Profitability has positive influences on HCD and SCD. According to Mondal and Ghosh (2014), companies with greater profits will disclose their ICs so as to attract the attention of stakeholders that they have better performance (Ousama, et al., 2012) and avoid shares below their true value (Dominguez, 2012).
Statistically, leverage has no effect on ICD. This supports the studies of Mondal and Gosh (2014) as well as Jindal and Kumar (2012), and may happen when the debtors place more importance on financial information as it better reflects financial risks. The presence of other media such as debt covenants also help monitoring management's decision, using other information than the firm's disclosure (Nazir et al., 2012).

\section{CONCLUSION}

This study provides empirical evidence on the effect of auditor type, the board size, and audit committee on ICD in Indonesia's agriculture and mining sectors. Auditor type has a positive relationship with ICD, particularly on the component of SCD. The audit committee also has a positive association on ICD, especially on HCD and SCD. Meanwhile, a negative relationship is found between board size and ICD, in particular on HCD and SCD. The roles of an audit committee and external auditor are to give users confidence in reports published by the company. In addition to increasing the credibility of a disclosure, the audit process can reduce information gaps. Therefore, auditors can encourage management to improve the quality of disclosures so that published reports can describe the real situation so that the value of the company does not undervalue. The existence of the audit committee should be able to improve internal control and be a monitoring tool in improving the quality of ICD. In addition, the audit committee is responsible for reviewing issues in significant reporting and relating to valuable information. Therefore, an effective audit committee can increase the disclosure of information, especially regarding ICD. The Smith Report (2003) recommends that audit committee members consist of at least three independent and non-executive directors. Thus, the audit committee can work more effectively with clearer responsibilities so that the monitoring process can be carried out properly.

Board size shows a negative influence on ICD quality. This negative coefficient can be caused by poor quality disclosure. What is likely to happen is that when the council has more members, more interests will have to be fulfilled. To fulfill this, it takes effort and costs to disclose. The company will consider the costs and benefits that will be obtained so that when the costs exceed the benefits, the company will continue to disclose in narrative or descriptive form to further save costs.

Market share, profitability, and leverage, as control variables, give mixed results to the quality of 
IC disclosure. When the company has gained public trust and a good reputation, it would be better for the company to also reveal how the company manages human resources such as training, capacity building, employee retention and others. This disclosure will further strengthen investor confidence in the company. Companies can increase the disclosure of ICD items that are still not optimal, such as business models, intellectual property, brand recognition and others. In addition, disclosures such as research and development and technology can be accompanied by numerical and monetary data such as costs incurred to develop products, maintenance costs or the cost of purchasing new technology, or the useful life of the technology used. Numerical and monetary disclosures can improve the quality of disclosure.

This research contributes to prior studies as there were not many studies of intellectual capital on the sectors agricultural and resources. It has several limitations. The data obtained in the study were only from annual and financial reports, while there is a possibility that companies would provide intellectual capital information through other media, such as the disclosures in the company website. The content analysis is done manually where each score is given based on the consideration or judgment of the researcher. Despite repeated checks among researchers, future studies can use special software such as NVIVO for more accurate results.

\section{REFERENCES}

Abeysekera, I. (2010). The influence of board size on intellectual capital disclosure by Kenyan listed firms. Journal of Intellectual Capital, 11(4), 504-518.

Ahmadi, A., \& Bouri, A. (2017). The effect of audit quality on the extent of voluntary disclosure: Companies listed in the Tunisian stock exchange. Journal of the Knowledge Economy, 10(1), 59-73.

Ahmed Haji, A. (2015). The role of audit committee attributes in intellectual capital disclosures. Managerial Auditing Journal, 30(8/9), 756784.

Al Azees, H. A. R., Sukoharsono, E. G., Roekhudin, \& Andayani, W. (2019). The impact of board characteristics on earning management in the international oil and gas corporations. Academy of Accounting and Financial Studies Journal, 23(1), 1-26.

Alizadeh, R., Chashmi, S. A. N., \& Bahnamiri, A. J. (2014). Corporate governance and intellectual capital. Management Science Letter, 4, 181186.

Allegrini, M., \& Greco, G. (2011). Corporate boards, audit committees and voluntary disclosure: evidence from Italian Listed Companies. Journal of Management and Governance, 15(3), 1-30.

An, Y., Davey, H., \& Eggleton, I. (2011). Towards a comprehensive theoretical framework for voluntary IC disclosure. Journal of Intellectual Capital, 12(4), 571-585.

Atan, R. \& Rahim, A. (2012). Corporate reporting on intellectual capital: Evidence from ace market of bursa Malaysia. IEE, 1021-1026 Aygun, M., Ic, S., \&Sayim, M. (2014). The effects of corporate ownership structure and board size on earnings management: Evidence from Turkey. International Journal of Business and Management, 9(12),123-126

Bagchi, D., Joshi, P.L., \& Salleh, N.M.Z.N. (2015). The extent of disclosure on implicit capital and firm's characteristics: Malaysian experience. International Journal of Learning \& Intellectual Capital, 12(2), 170-192.

Berzkalne, I., \& Zelgalve, E. (2014). Intellectual capital and company value. Procedia - Social and Behavioral Sciences, 110, 887-896.

Bhasin, M. (2012). Measurement and Disclosure of Intellectual Capital: Evidence from a Developing Country. International Journal of Finance and Accounting, 1(5), 82-93.

Bhatia, M., \& Agarwal. B (2015). Intellectual Capital Disclosures in IPO Prospectuses of Indian Companies. International Journal of Social Sciences and Management, 2(1).

Bruggen, A., Vergauwen, P., \& Dao, M. (2009). Determinants of intellectual capital disclosure: Evidence from Australia. Management Decision, 47(2), 233-245.

Buallay, A. (2018). Audit committee characteristics: an empirical investigation of the contribution to intellectual capital efficiency. Measuring Business Excellence, 22(2), 183-200.

Cerbioni, F., \& Parbonetti, A. (2007). Exploring the effects of corporate governance on intellectual capital disclosure: An analysis of Europe and biotechnology companies. European Accounting Review, 16(4), 791-826.

Cerbioni, F., \& Parbonetti, A. (2007). Exploring the effects of corporate governance on intellectual capital disclosure: An analysis of Europe and biotechnology companies. European Accounting Review, 16(4), 791-826.Chao, G. 
\& Gray, S. J. (2010). Family ownership, board independence and voluntary disclosure: Evidence from Hong Kong. Journal of International Accounting, Auditing, \& Taxation, 19, 93-104

Cheng, M.Y., Lin, J.Y., Hsiao, T.Y. \& Lin, T. W. (2010). Invested resource, competitive intellectual capital, and corporate performance. Journal of Intellectual capital, 11(4), 433-450.

Chowdhury, L., Rana, T., Akter, M., \& Hoque, M. (2018). Impact of intellectual capital on financial performance: evidence from the Bangladeshi textile sector. Journal of Accounting and Organizational Change, 14(4), 429-454.

Èepar, Ž., \& Bojnec, Š. (2008). Population aging and the education market in Slovenia and Croatia. Eastern European economics, 46, 6886.

Domínguez, M. Á. (2012). Company characteristics and human resource disclosure in Spain. Social Responsibility Journal, 8(1), 4-20.

Dwiarto, D (2018). Pertambangan masih menjadi tulang punggung keluarga. Indonesia Mining Association. Retrieved Feb 20 $0^{\text {th }}, 2019$ from http://www.ima-api.com/index.php?option= com_content\&view $=$ article $\& \mathrm{id}=3547 \% 3$ Apertambangan-masih-jadi-tulang-punggung$\mathrm{n}$ e g a r a $\& \mathrm{c}$ a t id $=47 \% 3 \mathrm{~A} \mathrm{media-}$ news\&Itemid $=98 \&$ lang $=\mathrm{id}$

Ferreira, A. L., Branco, M. C., \& Moreira, J. A. (2012). Factors influencing intellectual capital disclosure by Portuguese companies. International Journal of Accounting \& Financial Reporting, 2(2). doi:10.5296/ijafr.v2i2.2844.

Freeman, R. E. (1994). The Politics of Stakeholder Theory: Some Future Directions. Business Ethics Quarterly, 4(4), 409-421. doi:10.2307/ 3857340

Guthrie, J., Petty, R., Yongvanich, K., \& Ricceri, F. (2004). Using content analysis as a research method to inquire into intellectual capital reporting. Journal of Intellectual Capital, 5(2), 282293.

Guthrie, J., Ricceri, F., \& Dumay, J. (2012). Reflections and projections: A decade of Intellectual Capital Accounting Research. British Accounting Review, 44(2), 68-82.

Haji, A. A., \& Ghazali, N.A.M. (2013). A longitudinal examination of intellectual capital disclosures and corporate governance attributes in Malaysia. Asian Review of Accounting, 12(1), 2752.
Hermannsson, K., \& Lecca, P. (2014). Human capital investment and population growth: An overlapping generations analysis for Malawi," EcoMod2014 6823, EcoMod.

Hidalgo, R., Garcia-Meca, E., \& Martinez, I. (2011). Corporate governance and intellectual capital disclosure. Journal of Business Ethics, 100(3), 483-495.

Ho, S.S.M, \& Wong, K.S. (2001). A study of the relationship between corporate governance structures and the extent of voluntary disclosure. Journal of International Accounting, 10(2), 139-156.

Hossain, M. (2011). Intellectual capital reporting in a South Asian country: Evidence from Bangladesh. Journal of Human Resource Costing \& Accounting, 15(3), 196-233.

Iraya C., Mwangi, M., \& Muchoki, G. (2015). The effect of corporate governance Practices on earnings management of Companies listed at the Nairobi Securities Exchange. European Scientific Journal, 11(1) 169-178

Jindal, S., \& Kumar, M. (2012). The determinants of HC disclosures of Indian firms. Journal of Intellectual Capital, 13(2), 221-247

Kamath, B. (2017). Determinants of intellectual capital disclosure: Evidence from India. Journal of Financial Reporting and Accounting, 15(3), 367-391.

Kementrian Pertanian Republik Indonesia (2017). FAO: Indonesia dan Thailand produsen beras terbesar di dunia. Retrieved March 24 $4^{\text {th }}, 2019$ from http://www.pertanian.go.id/home/ ?show=news\&act $=$ view\&id $=2342$

Khlif, H. \& Souissi, M. (2010). The determinants of corporate disclosure: a meta-analysis. International journal of accounting and information management, 18(3), 198-219

Kijboonchoo, T., Kulchanachutiporn, C., \& Soralam, N. (2018). A structural analyses of ten economies in ASEAN economic community. Assumption Journal, 38(1), 18-29.

Klein, A. G., Gerhard, C., Biichner, R. D., Diestel, S. and Schermelleh-Engel, K.(2016), The detection of heteroscedasticity in regression models for psychological data, Psychological Test and Assessment Modeling, 58(4), 567-592.

Kothari, S. P. (2000). The Role of Financial Reporting in Reducing Financial Risks in the Market. in E. S. Rosengren and J. S. Jordan(eds.), Building an Infrastructure for Financial Stability ( $p p$. 89-102), (Federal Reserve Bank of Boston Conference Series, No. 44), 
Li, J., Mangena, M., \& Pike, R. (2012). The effect of audit committee characteristics on intellectual capital disclosure. The British Accounting Review, 44(2), 98-110.

Maaloul, A., \& Zéghal, D. (2015). Financial statement informativeness and intellectual capital disclosure: An empirical analysis. Journal of Financial Reporting and Accounting, 13(1), 6690.

Madi, H. K., Ishak, Z., \& Manaf, N. A. A. (2014). The impact of audit committee characteristics on corporate voluntary disclosure. Social and Behavioral Sciences, 16, 486 - 492

Malone, D., Fries, C. \& Jones, T. (1993). An empirical investigation of the extent of corporate financial disclosure in the oil and gas industry. Journal of Accounting, Auditing and Finance, 8(3), 249-73.

Massingham, P.R., \& Tam, L. (2015). The relationship between human capital, value creation and employee reward. Journal of Intellectual Capital, 16(2), 390-418.

Mondal A., \& Ghosh (2014). Determinants of intellectual capital disclosure practices of Indian companies. Journal of Commerce and Accounting Research, 3(3), 25-36.

Mukhibad, H., \& Setyawati, M E. (2019). Profitabilitas Pemoderasi Determinan Pengungkapan Modal Intelektual. Jurnal Ilmiah Akuntansi dan Bisnis, 14(1), 120-131.

Nazir, M.S., Saita, H.K., Ahmed, I., \& Nawaz, M.M. (2012). The impact of financial leverage on agency cost: Empirical evidence from non-financial sector on Pakistan. Science Series Data Report, 4(6), 79-94.

Oliveira, L., Rodrigues, L.L., \& Craig, R. (2006). Firm-specific determinants of intangibles reporting: evidence from the Portuguese stock market. Journal of Human Resource Costing and Accounting, 10(1), 11-33.
Ousama, A.A., Fatima, A.H., \& Majdi, A.R. (2012). Determinants of intellectual capital reporting: Evidence from annual reports of Malaysian listed companies. Journal of Accounting in Emerging Economies, 2(2), 119 - 139.

Oxford Business Group (2018). Indonesia's mining sector seeks to boost downstream activity. Retrieved March 23rd, 2019 from https:// oxfordbusinessgroup.com/overview/balancingact-low-commodity-prices-and-drive-bolsterdownstream-activity-require-nuanced-approach

Rashid, A. A., Ibrahim, M. K., Othman, R., \& See, K. F. (2012). IC disclosures in IPO prospectuses: evidence from Malaysia. Journal of Intellectual Capital, 13(1), 57-80.

Roos, G., \& Roos, J. (1997). Measuring your company's intellectual performance. Long Range Planning, 30(3),413-426.

Sveiby, K. E. (1997). The New Organizational Wealth: Managing and Measuring Knowledge Based Assets. Page 275

Smith Report. (2003). Audit committees: combined code guidance. London: FRC.

Whiting, R.H., \& Birch, G.Y. (2016). Corporate governance and intellectual capital disclosure. Corporate Ownership and Control, 13(2), 250-261.

Whiting, R.H., \& Woodcock, J. (2011). Firm characteristics and intellectual capital disclosure by Australian companies. Journal of Human Resource Costing and Accounting, 15(2), 102 - 126.

Yau, F.S., Chun, L.S., \& Balaram, R. (2009). Intellectual capital reporting and corporate characteristics of public-listed companies in Malaysia. Journal of Financial Reporting and Accounting, 7(1), 17-35. 